\title{
"Coisas do mundo, minha nega": para uma poética de Paulinho da Viola
}

\author{
RoBERTO BOZZETTI \\ Universidade Federal Rural do Rio de Janeiro (Seropédica, Brasil)
}

\begin{abstract}
RESUMO: ESTE TRABALHO DISCUTE A INSERÇÃO DA ASSINATURA PAULINHO DA VIOLA NO UNIVERSO DA CANÇÃO MEDIATIZADA BRASILEIRA NA DÉCADA DE 1960. PERTENCENTE AO MUNDO DO SAMBA CARIOCA, O POETA RECUSA, NO ENTANTO, OS ESTEREÓTIPOS QUE O CERCAM, EM ESPECIAL O DA MALANDRAGEM E O DA AUTENTICIDADE NACIONAL: SEU INTERESSE ESTÁ NO APRENDIZADO DAS "COISAS DO MUNDO".
\end{abstract}

ABSTRACT: THIS PAPER DISCUSSES THE INCLUSION OF THE SIGNATURE PAULINHO DA VIOLA IN THE UNIVERSE OF BRAZILIAN POPULAR SONG MEDIA IN THE 1960S. BECOMING FROM THE SAMBA OF RIO DE JANEIRO, HOWEVER THE POET REFUSES THE STEREOTYPES THAT SURROUND ITS CONDITION, ESPECIALLY THAT OF THE TRICKERY AND NATIONAL AUTHENTICITY: HIS INTEREST IS IN LEARNING THE "THINGS OF THE WORLD."

PALAVRAS-CHAVE: CANÇÃO MEDIATIZADA - SAMBA - POESIA, POÉTICA. KEYWORDS: BRAZILIAN POPULAR SONG - SAMBA - POETRY, POETICS. 
m 1968, Paulinho da Viola lançou seu primeiro LP individual, contendo, entre outras canções, "Coisas do mundo, minha nega". Havia já três anos ele ingressara no mundo fonográfico, atuando como acompanhante ou compartilhando canto e autoria de canções com outros artistas ligados ao samba tradicional. Em 1968, Paulinho está participando, ainda que de forma um tanto discreta, do final do processo que culminou com aquilo que Marcos Napolitano chamou de consolidação da "instituição MPB" (NAPOLITANO, 2001), processo este que tivera início em fins da década de 50, com a bossa nova.

Ao longo da década de 60, após a "fase ortodoxa" da bossa nova (195862), o panorama da canção mediatizada no Brasil se diversifica: retomam-se os debates que envolveram principalmente as forças da concepção de uma arte nacional-popular, oriundas dos anos 30 e agora encarnadas na "canção de protesto", em geral de fundo "folclorizante"; logo a seguir, assiste-se à crítica desta concepção empreendida pelos tropicalistas. Assim, ao fim de um curso de aproximadamente dez anos se chega a um quadro de maior definição quanto aos papéis e funções dos agentes em jogo: o tropicalismo encerra seu período heróico (final de 1967 a final de 68) em momento que assiste à exacerbação repressiva no quadro político-institucional no país com a decretação do Ato Institucional n ${ }^{\circ} 5$ pela ditadura militar, concomitantemente à decisiva implantação da cultura audiovisual e à tentativa de estruturação (obstaculizada naquele momento em boa medida pelo quadro repressivo) da indústria fonográfica, em bases que se queriam mais condizentes com uma verdadeira racionalidade capitalista. Essas as linhas gerais de um processo que consagrou a geração de cancionistas que se lançara nos "festivais de música na TV', certames competitivos que popularizaram definitivamente os nomes de Chico Buarque, Caetano Veloso, Gilberto Gil e vários outros. Seu sentido maior foi o estabelecimento da "MPB instituição sociocultural", e esta, por sua vez, segundo o mesmo Napolitano, o de "consolidar o deslocamento do lugar social da canção".

Entenda-se, por essa última expressão, o fato de que a canção que se gravava em disco e se ouvia em rádio no Brasil, ou seja, a canção mediatizada, foi saindo a partir dos anos 20, de um lugar social lugar não legitimado pela maior parte do segmento das elites letradas, lugar de um showbussiness incipiente, o qual poderia ser designado como o do simples entretenimento, sem nenhuma pretensão de vir a ter por parte dessas elites maior consideração 
artística. É um distanciamento - para não dizer indiferença - intelectual que lemos, por exemplo, em Drummond, ainda em 1962, glosando com ironia (auto)complacente em Lição de coisas a "música barata": "Paloma, Violetera, Feuilles Mortes,/Saudades do Matão e de mais quem?/A música barata me visita/e me conduz para um pobre nirvana à minha imagem."

Ora, em fins dos anos 20, num verdadeiro crossover no campo da sociologia da cultura, a "música barata" inicia um percurso que, trinta a quarenta anos depois, a inscreverá numa fronteira tensa entre três lugares (mal)ocupados: primeiro, o daquele mesmo mundo desprestigiado de onde proviera, ou seja, o mundo do disco e dos auditórios de rádio - logo, portando seus vestígios, o que muitas vezes seria conveniente esconder; segundo, o de um possível locus percebido como "popular", que poderia ser valorizado, pela intelectualidade modernista e seus herdeiros, desde que pelo termo "popular" se entendesse o idealizado sob uma designação como a de "folclore"; e, terceiro, finalmente, mas não apenas, o lugar de uma desconfortável (e almejada) inserção em uma indústria cultural em momento decisivo (anos 60/70), inserção esta ainda que feita a partir de conteúdos e formas que se queriam libertários e renovadores, mais do que seriam em suas formulações propriamente populares (cabem aqui a bossa nova e sua imediata continuidade na MPB).

Essa inserção de impulso libertário, por assim dizer, já era sintoma, por si só, do tipo de apropriação do popular por camadas sociais mais identificadas com a cultura letrada, a que se acrescentaria um certo "espírito do tempo", naquele período especialmente fecundo em discussões, apropriações e em proposições políticas, como foram os anos 60. Para iconizar os exemplos de como nossos modernistas históricos e seus herdeiros lidavam com esse quadro: a partir de agora (anos 60), a atitude blasé (para dizer o mínimo) de Drummond teria que conviver com as dramáticas tentativas dos herdeiros do nacionalismo de um Mário de Andrade (morto há alguns anos) para separar o "populário" do que seria contaminado pelo "urbanismo deletério" (o "popularesco"), tendo ainda que conversar com outro par célebre, o Vinícius de Moraes que àquela altura já cantava as garotas de Ipanema e "peixinhos e beijinhos e abraços sem ter fim" - e que, ao fazer o trânsito entre o "alto" e o "baixo" do espectro cultural, era visto, justo por isso, com crescente desconfiança pelos setores mais conservadores. Parecia que se cumpria mais uma das profecias oswaldianas e vivia-se, tal como se lera no Manifesto pau-brasil do dis- 
tante 1924, reposto em circulação por concretistas e tropicalistas, uma realidade que já ia até mesmo bem além daquela formulada no 1 como "sala de jantar domingueira, com passarinhos cantando na mata resumida das gaiolas, um sujeito magro compondo uma valsa para flauta e a Maricota lendo o jornal" - a que agora se juntava a onipresença dos aparelhos de TV. Mediatizando-se, isto é, fazendo-se ouvir através da mediação do disco, e ganhando espaço na TV, originando-se de criadores que mais e mais se identificavam com o paradigma de herdeiros do modernismo (em sua maioria os novos nomes da cena musical, da "MPB", possuíam extração universitária) e/ou buscavam - como os próprios modernistas o haviam feito - dialogar ou mesmo simplesmente apropriar-se de práticas culturais "tradicionais" ou "populares" (o folclore, o samba), a canção, agora com foros de cidadania artística, configura-se como o mais bem realizado exemplar, pelo menos no Brasil, da hibridação cultural de que fala Néstor García Canclini, exemplificando algo que se dá como produto e transita no interior de "processos socioculturais nos quais estruturas ou práticas discretas, que existiam de forma separada, se combinam para gerar novas estruturas, objetos e práticas"(CANCLINI, 2004, p. XIX ).

Os novos cancionistas daqueles anos começavam por erigir uma obra que em última análise herdaria muitas das discussões que vinham do modernismo e buscaria dialogar com as novas forças discursivas em cena. Entre estas, principalmente, a da indústria cultural, que se estruturava a partir do disco, mais precisamente o LP, o novo objeto de desejo e fruição das classes médias urbanas agigantadas ao influxo da modernização conservadora triunfante com o golpe de 64. Foi precisamente essa geração de artistas que em meados dos anos 60, na faixa etária dos 20 anos, sedimentou o suporte LP. Este, por sua vez, abrigou e legitimou suas obras, firmando-lhes os nomes como os de uma "geração autoral" de cancionistas. Vale notar, embora não seja o fulcro do principal desenvolvimento aqui, que a dimensão autoral para o disco LP teve para esses novos nomes um estatuto aproximável ao do livro para os nomes da série literária. Também por essa via se deu a aproximação da MPB com práticas de produção artística e recepção habituais na cultura letrada. Como se falava antes na obra dos autores literários, no mundo do livro, agora os autores da canção mediatizada mais e mais se tornarão identificáveis como autores de obras musicais: o LP de um Chico Buarque seria análogo ao que era vinte ou trinta anos antes, digamos, o livro de um Manuel Bandeira. 
Em todo esse processo de estreitamento de relações entre o mundo da canção mediatizada (a MPB) e a cultura letrada, em especial a produção literária advinda do modernismo, é preciso entender a importância que adquire a bossa nova como o momento em que a canção se moderniza no preciso sentido de incorporar decisivamente uma consciência crítica dos processos de composição. É certo que na tradição anterior isso já despontara, principalmente em Noel Rosa nos idos de 30, mas no sentido sistemático e construtivo, abrangendo também a feitura musical - sobretudo, pela incorporação também sistemática de novas componentes harmônicas, além do canto e da orquestração - a bossa nova operou uma incisão metalinguística que naquele momento foi sentida como ruptura. Como diz Antônio Cícero, se até então "toda a música popular brasileira (...) queria ver-se como tradicional, a bossa nova se jactava de ser nova; e, evidentemente, o era” (CÍCERO, 2003, p. 202). Como a reflexão crítica sobre esses processos já estava bastante amadurecida depois de meio século de modernismo e em função dos outros fatores acima apontados, a bossa nova fica como um marco fundador, um divisor de águas aos olhos dos jovens cancionistas. É sobejamente sabido o quanto todos eles, de Caetano Veloso a Chico Buarque, passando por Gilberto Gil, Edu Lobo e mesmo aqueles menos próximos dessa nova modalidade digamos "intelectualizada" da canção popular, como Roberto Carlos, rendem tributo e reconhecem o momento decisivo em suas vidas da audição do primeiro disco de João Gilberto. Grande foi também o impacto sobre Paulinho da Viola que, no entanto, naquele momento, juntava o choro ortodoxo de sua formação - seu pai era músico de rádio e de estúdio, acompanhante de Jacob do Bandolim e de outros luminares desse gênero instrumental carioca - às suas primeiras incursões em universo mais próximo deste, o samba tradicional também carioca, ligado aos subúrbios e morros. Assim, Paulinho se portou com mais distanciamento reticente do que seus pares, embora nunca tenha negado a admiração que a arte de Tom Jobim e João Gilberto lhe suscitou. Porque, mais do que em qualquer de seus pares de geração, na arte de Paulinho da Viola os impulsos renovadores, modernizantes da canção daqueles anos parecem perturbar de dentro o aprendizado de uma tradição de onde ele houvera partido em bases muito sólidas: e fique ainda aqui a informação de que, a partir do advento da bossa nova, não apenas a música, mas os músicos profissionais praticantes dessas modalidades subitamente "antigas" se viram lançados a 
uma espécie de limbo. Dá-se então uma espécie de cena dramática em que de um lado está a inscrição numa linhagem clássica (o termo é o mais apropriado, por supor um aprendizado em continuidade) do samba e do choro e, de outro, a perturbação da ruptura própria do que o moderno opera em relação ao clássico. Acrescente-se: diferente do que é ainda hoje corriqueiro, embora em menor escala, em Paulinho não se assiste a uma atitude "defensivista" do "samba autêntico", muito pelo contrário: em sua obra, o período que vai de 1968 a 1976 é movido por essa tensão, no nível mais amplo de uma poética cancional, vale dizer: em termos propriamente musicais - incluindo arranjo, acompanhamento e orquestração - e poéticos. Mas também não há nenhuma entrega pura e simples ao novo: há uma reflexão que se vai amadurecendo ao longo de sua trajetória e que lhe confere um papel absolutamente único no panorama geral da canção mediatizada brasileira até hoje. Na canção de que tratarei aqui, marco inicial de excelência, essas forças em tensão se presentificam: é o que pretendo demonstrar.

\section{COISAS DO MUNDO, MINHA NEGA}

Hoje eu vim, minha nega

Como venho quando posso

$\mathrm{Na}$ boca as mesmas palavras

No peito o mesmo remorso

Nas mãos a mesma viola

Onde gravei o teu nome

Nas mãos a mesma viola

Onde gravei o teu nome

Venho do samba há tempo, nega

Vim parando por aí

Primeiro achei Zé fuleiro

Que me falou de doença

Que a sorte nunca lhe chega

Está sem amor e sem dinheiro

Perguntou se eu não dispunha 
De algum que pudesse dar

Puxei então da viola

Cantei um samba pra ele

Foi um samba sincopado

Que zombou de seu azar

Hoje eu vim, minha nega

Andar contigo no espaço

Tentar fazer em teus braços

Um samba puro de amor

Sem melodia ou palavra

Pra não perder o valor

Sem melodia ou palavra

Pra não perder o valor

Depois encontrei seu Bento, nega

Que bebeu a noite inteira

Estirou-se na calçada

Sem ter vontade qualquer

Esqueceu do compromisso

Que assumiu com a mulher

Não chegar de madrugada

E não beber mais cachaça

Ela fez até promessa

Pagou e se arrependeu

Cantei um samba pra ele

Que sorriu e adormeceu

Hoje eu vim, minha nega

Querendo aquele sorriso

Que tu entregas pro céu

Quando eu te aperto em meus braços

Guarda bem minha viola

Meu amor e meu cansaço 
Guarda bem minha viola

Meu amor e meu cansaço

Por fim eu achei um corpo, nega

Iluminado ao redor

Disseram que foi bobagem

Um queria ser melhor

Não foi amor nem dinheiro

A causa da discussão

Foi apenas um pandeiro

Que depois ficou no chão

Não tirei minha viola

Parei, olhei, vim-me embora

Ninguém compreenderia

Um samba naquela hora

Hoje eu vim, minha nega

Sem saber nada da vida

Querendo aprender contigo

A forma de se viver

As coisas estão no mundo

Só que eu preciso aprender

As coisas estão no mundo

Só que eu preciso aprender

Um simples exame da extensão do texto indica o quanto se trata de uma "canção de festival", característica daqueles anos: são 68 versos, divididos em três longas estrofes de 12 versos entremeadas por quatro estrofes menores de 8 versos (na verdade sextilhas, com os versos finais repetidos). O tipo de composição mais adotado por Paulinho é o samba com primeira e segunda partes, bem característica, de resto, da composição tradicional de samba. Lógico que há variações a esse esquema, sendo a mais habitual aquela que de certa forma é tributária da estrofação do partido-alto, com refrãos recorrentes alternando-se com estrofes de maior extensão. Mas não é em absoluto o caso aqui. Ocioso dizer ainda que "Coisas do mundo" não adota um tipo de texto exclusivo de festi- 
vais, mas sim que era bastante habitual naqueles certames. Esse modelo, presente em diversas canções dos cancionistas que se lançaram por essa época, com variações admissíveis pela maior ou menor ocorrência de refrãos, hipertrofiava a letra, que por sua vez se distribuía por uma melodia cujo desenvolvimento era menor em relação ao texto. Pode-se dizer que se atesta aí uma supervalorização do plano verbal, próprio da camada de cancionistas letrados, universitários, que, no contexto específico dos anos 60, veiculava seus "recados" em letras de canções, participantes ou não (algumas das canções celebrizadas nos festivais, de variada autoria, com letras de grande extensão: "Disparada", "Roda viva", "Domingo no parque", "Ponteio", "A estrada e o violeiro", "Beto bom de bola", "Andança") o que no fundo correspondia a uma espécie de crença no poder transformador da cultura. Que o procedimento habitual de Paulinho da Viola não tenha sido o vezo de compor segundo o modelo consagrado das canções de festival é fato: mas essa canção pagou seu tributo a essa estética, até porque Paulinho partilhava com seus pares a crença no tal poder transformador a partir da discussão cultural. E em "Coisas do mundo, minha nega" isso se manifesta (no sentido derivado também de manifesto, tal como se entende nas artes do século XX), enquanto ato criador, embora sem alarde, propondo uma poética. "Inenfática", um pouco à maneira da voz interior da pedra, no poema de João Cabral de Melo Neto.

Mas ao contrário de seus pares geracionais, Paulinho nunca fora exatamente bem sucedido nos certames "festivalescos" de então, o que se alteraria em 1969 com a vitória de "Sinal fechado". "Coisas do mundo" obteve apenas um pálido sexto lugar na Bienal do Samba, o que parecia confirmar essa presença esmaecida. Talvez entre as coisas que era "preciso aprender" no mundo se incluísse naquele momento, em interpretação prosaica, "como vencer festivais". Mas que esta tirada não se esgote no anedótico, uma vez que sair-se bem em festivais era um ritual de passagem a que seus pares se submeteram, de forma mais ou menos consciente e mais ou menos resignada em cada caso, e de onde eles extraíram a parte mais significativa de seus capitais simbólicos na entrada no mundo da indústria fonográfica e da televisão.

Chegando agora um pouco mais perto do texto da canção, vemos que ela se estrutura como uma narrativa do cotidiano: o narrador chega aonde sua "nêga" o espera, e chega desculpando-se, como de hábito: "na boca as mesmas palavras". Serão estas, ou melhor, sua reincidência, a razão do "mesmo 
remorso", atenuando o "venho quando posso". E a viola (no Brasil, uma forma carinhosa de se tratar a guitarra, a que chamamos "violão") com o nome da amada gravado quer servir de álibi, num expediente que acena muito sutilmente a um expediente habitual da malandragem: o agrado à companheira pelo retorno fora de hora do boêmio.

Cumprido o ritual das desculpas, apresentada a cena situacional da elocução, explicita-se a narrativa: procedendo do samba "há tempo", o narrador encontra um primeiro personagem, mais anônimo ainda do que o João Gostoso bandeiriano, um certo fuleiro (insignificante, reles) chamado Zé Fuleiro. E de imediato, a primeira oração adjetiva, introduzida pelo "que", desdobrase em objetiva direta no rosário de reclamações do tal personagem, todas em torno de sua má sorte na vida, comum a todos os fuleiros zés, até resolver-se, em sua fala, no expediente malandro da "facada", que como se sabe é gíria antiga para pedir dinheiro emprestado: "perguntou se eu não dispunha/de algum que pudesse dar". O desdobrar-se de lamentações do malandro Zé Fuleiro é, de certa forma, análogo ao desdobrar-se detalhado das explicações do sambista à sua "nega". Isso se reforça na letra pelo acúmulo de situações narradas em torno da mala suerte, como já destacado, levando o texto a arrastar-se numa espécie de "conversa mole", num desfiar pouco convincente e banal de desculpas mal alinhavadas. Como antídoto a isso, o que a malandragem receitaria? A zombaria em forma de samba sincopado, que corta abruptamente o que ameaçava tornar-se enfadonho: "puxei então...". Esse "então" aí cumpre o papel de encaminhador do arremate, arremate este reforçado pelo recurso à rima aguda que fecha a estrofe em “azar". A esse respeito, observe-se que o recurso à rima é irregular na estrofe (aliás, em todas), mas este verso em aguda é rimado com o oitavo verso, também em final bem tônico, justamente a passagem em que se revela a intenção até então oculta do malandro na "facada".

Passemos agora a algumas considerações sobre a eficácia de "Coisas do mundo, minha nega", entendida como realização de uma dicção da canção nos moldes semiológicos propostos por Luiz Tatit. Tatit entende pelo termo "dicção" a combinação semiótica de letra-e-música, na qual avulta, decisiva, a importância da entoação:

Cantar é uma gestualidade oral, ao mesmo tempo contínua, articulada, tensa e natural, que exige um permanente equilíbrio entre os elementos melódicos, 
linguísticos, os parâmetros musicais e a entoação coloquial (...). A grandeza do gesto oral do cancionista está em criar uma obra perene com os mesmos recursos utilizados para a produção efêmera da fala cotidiana. As tendências opostas de articulação linguística e continuidade melódica são neutralizadas pelo gesto oral do cancionista, que traduz as diferenças em continuidade. Num lance óbvio de aproveitamento dos recursos coloquiais, faz das duas tendências uma só dicção. E tudo soa natural, pois a maleabilidade do texto depende do tratamento entoativo. Um texto bem-tratado é sempre um bom texto. A melodia entoativa é o tesouro óbvio e secreto do cancionista. Compor uma canção é procurar uma dicção convincente. É eliminar a fronteira entre o falar e o cantar (TATIT, 1996, p. 10).

Importante para se apreender como Tatit localiza a produção de sentido na canção (qualquer canção) é entender os três tipos de compatibilidade acionados pela dicção do cancionista. Como vimos pela citação acima, Tatit chama diç̧ão à capacidade que deve ter o cancionista de compatibilizar as tendências opostas da continuidade melódica e da articulação linguística na canção, de modo que o resultado a que se chegue na junção de melodia-e-texto, que é a canção, corresponda a uma impressão de naturalidade entoativa "resolvida" no canto. A primeira compatibilidade faz-se sob a égide da identidade, entendida como aquilo que "faz com que um tema melódico se integre a seu semelhante assim como, na letra, um sujeito se define pela posse do objeto ou pelo acordo estabelecido com outro sujeito" (TATIT, 2001, p. 227). Tatit chama a esse processo tematização, pela recorrência constante de temas (motivos) melódicos e (sobretudo) rítmicos nos quais se espelha musicalmente a reiteração presente também no texto. São as canções de gênero mais definido (samba, xaxado, xote, rock, em suas formas mais castiças), nas quais há um continuum entre tematização linguística e musical, com ocorrência frequente, mas não necessária, de refrão.

À segunda compatibilidade Tatit chama passionalização e faz-se sob o fator de alteridade. Trata-se das canções de andamento mais lento, "valorizando (...) a duração de cada nota [e apresentando] temas melódicos até certo ponto diluídos", com tendência a se expandirem até o final de um percurso feito por desdobramentos. No plano melódico, isso equivale a dizer que se trata de canções onde maior se faz a exploração da tessitura. Diz-se que são regidas pela alteridade por 
serem canções de desencontro, de busca do outro, de ausência (entre sujeito e objeto), de tensões de sentimento, de falta. Aquilo que habitualmente se chama de "canções românticas" (samba-canção, ieieiê romântico, boleros, brega, etc) exemplificam bem essa segunda forma de compatibilidade melodia/letra.

Ao terceiro grupo de canções consideradas, Tatit chama de figurativizaçãa e faz-se sob a égide da produção de figuras. é onde se dá a maior aproximação entre fala e canto, chegando por vezes mesmo ao canto falado e, logicamente, ao coloquial. "Pela figurativização captamos a voz que fala no interior da voz que canta" (idem). São canções que, sob o aspecto melódico, estreitam a tessitura e ganham em "ginga", "manemolência" e nas quais se incorpora no canto certa imprevisibilidade própria da fala. Esse "processo geral de programação entoativa da melodia e de estabelecimento coloquial do texto pode ser denominada figurativização por sugerir ao ouvinte verdadeiras cenas (ou figuras) entoativas." É particularmente importante esse terceiro processo na confecção de sambas de breque, de sambas de acentuada síncopa, nas canções em forma de diálogo, e "até a perversão da melodia em função dos acentos das palavras, como corre na fala", de que seria exemplo "toda a obra de Jorge Ben Jor" e, acrescentaríamos, nas formas derivadas do rap e - por que não? - do repente.

Importa acrescentar que, como todo modelo teórico, tal divisão admite uma constante dinâmica de revezamento, integração e combinação dos três processos.

Tentando agora fazer render na canção examinada esses parâmetros de abordagem, podemos dizer que em "Coisas do mundo, minha nega" há o predomínio quase absoluto do que entendemos, segundo o modelo, por figurativização. Deixando de lado por ora as estrofes mais curtas que fazem o papel de refrão, ao examinarmos - não apenas a letra, mas também e principalmente o desenho melódico - as estrofes longas, notamos que a pouca exploração da tessitura corresponde ao encadeamento narrativo dos fatos anteriormente comentados. Isso vai totalmente de par não apenas com o deliberado coloquialismo do registro, como também com o caráter explicativo/ expositivo que a narração assume, ao ilustrar inicialmente as razões do atraso do boêmio. Há por vezes sequências inteiras de sílabas nas mesmas notas, e - considerando apenas a primeira estrofe longa, repita-se -, uma vez tendo se processado um salto intervalar este se mantém durante um tempo, acompanhando a letra, como se fosse desta o comando, como se o que se diz arti- 
culadamente, e que constitui a matéria linguística, subordinasse o continuum melódico. Observa-se ainda que, no início da explicação do personagem, na embocadura inicial ("Venho do samba há tempo") os saltos mais significativos corresponderiam a um determinado protocolo introdutório - como quem pisa de leve em assunto delicado -, seguido de uma aceleração da fala sem variação entoativa - como quem se apressa na rubrica da desculpa para o que vai ser exposto. Reforçando o que antes havia sido observado quanto à ocorrência da rima aguda ("dar/azar"), é de se notar que ambas se dão em elevações súbitas na condução melódica, em saltos de terça maior: em "algum que pudesse dar" reforça-se o momento da "facada", em que o malandro queixoso finalmente revela o porquê de tanta lamentação; em "que zombou de seu azar", procedimento análogo em região ainda mais elevada na melodia, o arremate zombeteiro leva a voz bem pra cima e "executa" um breque "premeditando" outro: este virá, surpreendente, na linha melódica das estrofes cuja ocorrência se repete a partir de "Hoje eu vim[breque] minha nega..."

$\mathrm{Na}$ verdade, nas estrofes curtas, introduzidas pelo verso acima citado, a tessitura melódica se expande notavelmente, contemplando saltos intervalares que chegam a atingir uma oitava. O impacto grande inicial vem precisamente da entoação nesse verso, que faz um movimento ascendente e, súbito, ao breque quase imperceptível faz suceder um movimento brusco descendente, perfazendo uma oitava. Notável ainda que em um texto todo costurado em redondilhas, o verso "Hoje eu vim, minha nega", que abre todas as ocorrências do refrão, seja um hexassílabo - como a esperar a sétima sílaba, que não vem. Na mesma estrofe - e nas demais que seguem esse feitio - a oscilação no campo da tessitura faz ressaltar a predominância do movimento descendente, que nos outros versos não se fará mais por saltos e sim por cadência (na primeira ocorrência do "refrão variável" é o que temos de "viola" até "nome" quando de sua segunda incidência na melodia), descida em escala nota a nota em direção ao repouso na tônica ré no modo maior. Recomenda a interpretação, se bem entendido foi o texto de Tatit, que isto deve ser lido como intensificação da passionalização, um estado de carência do outro, a expressão de um estado emocional em que a ação cede lugar à inação. E assim é, se considerarmos que na canção em questão essa carência do outro está contemplada na narrativa anterior (já que o narrador parte de um "venho" em que o ponto de chegada é junto à mulher), nas estrofes longas. As estrofes curtas são o correspondente ao espaço aonde se chega, 
onde se busca o abrigo ao mundo junto à mulher amada. Daí ser altamente significativo - no sentido semiológico mesmo - que a tensão final se resolva na dominante quando o último verso já está em sua segunda incidência, ou seja, comparece em recorrência. De fato, "onde gravei o teu nome", na primeira vez em que ocorre mantém a melodia em tensão até resolver-se plenamente no repouso da tônica (ré) quando de sua reiteração. Os sobressaltos contidos nos saltos ascendentes como que se amainam no rallentando que configura a feição melódica da estrofe curta em direção a seu final. As estrofes curtas são o momento de passionalização com que se entremeia o percurso predominantemente figurativo da narração nas estrofes longas. Mas não haveria aqui uma incoerência? A passionalização não implicaria disjunção, ao invés do encontro amoroso fruído da letra? Para bem entender o que proponho, encaminho uma análise mais detida do texto.

No segundo bloco narrativo, o narrador, vindo do samba, ainda mais avançada a hora em suas andanças, ("Depois...) depara-se com outro personagem: o bêbado largado no mundo, abúlico e abandonado. De novo o relato das desventuras a ser ouvido mais retardará a chegada do boêmio. As desventuras agora desfiadas, no entanto, não mais inspirarão como arremate a zombaria a ser comentada pelo samba sincopado; despertarão ternura, deflagradora do samba-acalanto, consolo do infeliz, que faz com que o bêbado adormeça sorrindo. Se no primeiro bloco narrativo a zombaria sincopada adequava-se perfeitamente, mas só do ponto de vista do cantor, à malandragem choramingosa de Zé Fuleiro, agora o samba integra-se de forma mais completa à harmonia (precária, sempre precária) do mundo, pois mostra-se adequado também à situação daquele a quem é dirigido (que "sorriu"). O samba constrói uma harmonia do mundo, é celebratório, a força do cantar-acalentar não está em "viver para consertar" o mundo no sentido de transformá-lo (como na "Disparada", de Vandré, como em tantas canções da época), mas de restaurar a harmonia de quem sofre. O todo da canção não passa a ilusão de uma harmonia do mundo, presentificada ou restaurada ou reivindicada que fosse através do samba; apenas se indica aqui nesta passagem uma harmonia propiciada pelo canto àquele (personagem, indivíduo, sujeito) que a perdeu; aqui a canção quase que perde totalmente suas arestas críticas (humor é sempre aresta crítica). Tal perda é tão-somente contrabalançada - o que não a faz total - pela presença quase imperceptível de outra frase clichê do samba, recorrente num sem-número de 
canções, a promessa de "não beber mais cachaça". Fazer o abúlico personagem adormecer é, portanto, fazê-lo esquecer também da promessa.

Podemos retomar agora de novo as duas ocorrências da estrofe curta, a que enceta e a que encerra esse bloco narrativo que acabamos de comentar. Leia-se novamente a segunda ocorrência do refrão. Aí tal estrofe é pura manifestação do desejo, o desejo do "samba puro", entendido como puro ato sexual, imersão no continuum absoluto, infenso a qualquer recorte que a realidade impura imponha ao ímpeto do prazer. Nem a melodia, sublimação a que a construção artística dá forma em clave de continuidade contígua à do puro estado, do "ser", muito menos a palavra, esta já mais recortada em sua natureza tendente à linearidade articulada, portanto à ação, ao "fazer." O samba em melodia-e-palavra é, nesse sentido comentado pelo cantor, menos "vital" que o samba puro. Para tentar esclarecer o que aqui se diz, recorro a uma citação de José Miguel Wisnik, no próprio livro de Tatit, que talvez ajude a reflexão sobre melodia-e-palavra:

O cantor apega-se à força do canto, e o cantar faz nascer uma outra voz dentro da voz. Essa, com que falamos, é muitas vezes a emissão de uma série de palavras sem desejo, emissões foscas e abafadas de um samba retraído, voz recortada pela pressão do princípio de realidade. Independentemente da intimidação da voz que fala, a fala mesma é dominada pela descontinuidade aperiódica da linguagem verbal; ela nos situa no mundo, recorta-o e nos permite separar sujeito e objeto, à custa do sistema de diferenças que é a língua. No entanto, o canto potencia tudo aquilo que há na linguagem, não de diferença, mas de presença. E presença é o corpo vivo: não as distinções abstratas de fonemas, mas a substância viva do som, força do corpo que respira.

Perante a voz da língua, a voz que canta é liberação: o recorte descontínuo das sucessivas articulações cede vez ao continuum das durações, das intensidades, do jogo das pulsações; as ondas menos periódicas da voz corrente dão lugar ao fluxo do sopro ritualizado pela recorrência (TATIT, 1996, p. 10). ${ }^{1}$

1. Grifo meu. É possível deslindar a reflexão de Wisnik de texto de Alfredo Bosi em O ser e o tempo da poesia, em especial a partir da reflexão seguinte: "O som do signo guarda, na sua aérea e ondulante matéria, o calor e o sabor de uma viagem noturna pelos corredores do corpo" (BOSI, 1977, p. 42). 
Pela gradação encadeada, mais presença que a voz do corpo (melodia) só o corpo, agente do "samba puro". No verso a melodia atinge o ponto culminante, a nota ré, lá onde a melodia ameaça esvanecer-se (apenas ameaça, afinal trata-se de uma canção...) e mergulha de novo em direção ao repouso.

É argumentável que a cada recorrência da estrofe curta, o desenho marcante da melodia em sua sinuosidade bem definida reitera as instâncias da passionalização até transformar-se - ou insinuar-se nessa direção - em tema, em tematização. Se, na lição de Tatit, deve-se conjugar passionalização com alteridade, se a "passionalização melódica é um campo sonoro propício às tensões ocasionadas pela desunião amorosa ou pelo sentimento de falta de um objeto de desejo"(TATIT, 1996, 23), como dizê-la predominante em trechos da canção em que se celebra o contrário disso, a conjunção, o encontro? Um caminho já foi insinuado quando se argumentou que a passionalização no caso traz, residual, a narrativa anterior da separação, ou melhor, da não-presença na cena (oculta) da anterioridade, do par homem-mulher (o poeta chega onde a mulher o aguarda). Mas não parece suficiente. Se considerarmos agora, segundo aquela mesma lição, que na tematização o fator identidade, o encontro (por oposição às considerações disjuntivas) é definidor, e se é justamente isso o que é celebrado nessas passagens, é necessário considerar a possibilidade de que a reiteração em si de um encadeamento melódico tão marcante (com o dado rítmico a mais, já realçado, de um breque sucessivo ao breque final das estrofes longas) transforme a passionalização em tematização. Sendo assim, que "relação motivada" seria criada por essa tematização, já que esta deve "satisfazer as necessidades gerais de materialização (linguístico-melódica) de uma idéia” (idem)? Prosseguir na análise do texto pode ajudar a responder. A estrofe curta que se segue ao segundo bloco mais longo, figurativo-narrativo, reitera a ocorrência da estrofe curta anterior, retomando precisamente a realização do "samba puro", integração não melodia-e-letra, mas homem-mulher.

Será o caso de remeter mais uma vez à terceira ocorrência do variável refrão. Nesta recorrência, a belíssima elipse dos versos 2, 3 e 4 contém uma das mais belas imagens do nosso cancioneiro para o ato sexual. A verticalidade do sorriso da amada que é entregue ao céu no momento do orgasmo nos braços do homem é reforçada musicalmente pela posição ocupada pela palavra "viola", no mais agudo da tessitura. Esse procedimento, por sua vez, retoma exatamente a ocorrência da mesma palavra na mesma posição em "nas mãos a mesma vio- 
la" da primeira ocorrência do refrão. A palavra torna-se prenhe de conotações sexuais: lá, nas mãos dele; aqui, guardada por ela. O repouso final novamente na tônica (ré) de "cansaço", a repetição do verso com a mesma palavra que "flutua" uma nota acima antes do repouso, todas essas recorrências, precisamente porque o são, tudo acaba por permitir falar em tematização a partir da reiteração de procedimentos entoativos (melódico-linguísticos) passionais. A imagem ("materialização de uma idéia") obtida pela conjugação de todos esses elementos, altamente passional, é a imagem do abrigo - abrigo a que chega o boêmio para repousar, junto à mulher, vindo dos embates com o mundo. Clareira, quase redoma em meio ao mundo. $\mathrm{O}$ mundo expresso na narrativa figurativizante, em que fala e melodia se estreitam e na qual aquela detém o comando, pois é preciso preencher o conhecimento do mundo a que (só) a fala permite acessar: aqui o limite em que a canção poderá pender para o texto irremediavelmente, poderá dar atenção ao "conteúdo" (como tanto se exigia da e na canção mediatizada então) e descartar a melodia (qualquer melodia) por "frívola", uma vez que a melodia não diz, não pode almejar estabelecer "verdades", relatos que testemunhem o desequilíbrio entre letra e melodia pode ser fatal, como foi nas canções mais inábeis da época, que lotaram os festivais (não aquelas que ficaram, não aquelas que sabemos cantar ainda hoje): se esta é a tendêncialimite (repita-se) das canções desse tempo festivalesco, longe dessa impotência fica "Coisas do mundo, minha nega", pois o personagem que a atravessa, assim como aqueles que encontra pelo caminho não porta nenhuma verdade preconcebida, aprende o mundo para aprender algo sobre si, que é justamente como aprender o mundo, como se verá no arremate. Benjamin diz que "na realidade não há narrativa alguma em que a pergunta: como continuou? pudesse perder o seu direito" (BENJAMIN, 1983b, p. 68). É bem isso que se dá quando se considera "Coisas do mundo, minha nega" mais que como letra, como figuração de uma situação elocucional específica do "tesouro oculto" da canção: junto a sua "nega" certamente as estórias do poeta continuarão a se emendar uma na outra. Podemos vislumbrá-lo no que é para nós o que o cantor belamente diz a sua amada: "querendo aprender contigo" - o aprendizado continuará a cada narrativa que ele lhe trouxer, não temos dúvida. No plano melódico, a clareira, introduzida pela súbita extensão da tessitura nos refrãos (variáveis), a cada nova recorrência converte sutilmente a passionalização em tematização da plenitude do encontro. A ligação deste momento de plenitude com o mundo figurativiza- 
do na narrativa é de distanciamento, é de curar o seu impulso para apenas dizer, é de realimentar o poeta que chega e encontra o porto seguro de chegada junto à mulher amada. A canção intensifica o sentido poético que há na consagração do instante, mostrando-nos "como" se faz essa consagração. Não mais se estenderá a letra, nem pode, uma vez que isso seria romper o limite magistral da dicção na direção do preenchimento de um "conteúdo" que alhearia a melodia. Acabaríamos por estar ante o enfadonho de uma letra longa demais ou uma portadora rebarbativa de verdades aprendidas.

No último bloco estrófico longo, a narrativa é retomada, desenhando-se o final do percurso na noite que se finda. Um corpo jaz, anônimo, abatido pela "bobagem" que o mundo parece não entender: "disseram que foi bobagem...". A disputa aponta para o motivo fútil do pandeiro. Posse? Não, duelo de perícia entre bambas: "Um queria ser melhor..." O boêmio resolve retomar seu caminho "de vinda", resignado em seu silêncio. Não que fosse precisamente o que coubesse, mas um samba ali, naquela hora, "ninguém compreenderia", e o poeta se cala, no mais previsível dos breques da canção, mas nem por isso menos significativo. Afinal, a vida prossegue e não deixa de surpreender que ao final dessa quase-fábula, o narrador revele "não saber nada da vida" em seu aprendizado tão minuciosamente narrado. Expediente malandro, algo da ordem do dito popular "o mundo inteiro não vale o meu lar", como justificativa de tantos desvios, tanto atraso, tanto adiamento, até finalmente abrigar-se junto da mulher? Se aceitarmos que "certa opacidade enganadora permeia implicitamente toda a linguagem malandra, um composto de naturalidade e afetação, que manobra de modo ambíguo sua comunicabilidade fluente entre o verdadeiro e o falso" (MATOS, 1982, p. 27) é certo que sim. Mas é justamente esse caráter "falador" do malandro (idem) que é sutilmente tensionado ao longo da canção. Pois é, em última instância, justamente essa ambiguidade que se inscreve como um limite em "Coisas do mundo, minha nega". A "moral esvaziada" dessa quase-fábula parece avançar um passo a mais na compreensão, no tensionamento e, certamente, no esgarçamento de um discurso malandro que, no fundo, quer ser deixado para trás. Está em cena a gloriosa luta do aprendizado do homem, necessariamente refratário ao lugar-comum. Parece que se cumprem nessa direção algumas etapas. Tentemos explicar.

Quando o narrador-boêmio indica que "vem do samba há tempo" o texto a seguir explicita figurativamente o reconhecimento de um "universo do 
samba". Os personagens que encontra pelo caminho são familiares a esse universo, assim como, "há tempo", também o próprio sujeito que canta, isto é: podemos ler como alguém que transita há muito tempo por esse universo, assim como, na dimensão "factual" do tempo narrado, saiu de "um samba", uma roda de samba, certamente, algumas horas antes de chegar ao encontro da amada: portanto, se os personagens são familiares por pertencerem ao "universo do samba" o são também pelo fato de o poeta os ter encontrado há pouco ("há tempo" para quem é movido pela ansiedade do encontro amoroso); os dois primeiros personagens são familiares ainda, ao que parece, ao homem e à sua "nega": nomeados, são "Zé Fuleiro" e “seu Bento". Familiares são também as estórias que os cercam, as palavras que usam, incorporadas ao discurso indireto do narrador. Tão banal - e tão velha - é a conversa malandra do primeiro, que o narrador não lhe dá o que ele esperaria. Malandragem com malandragem (do samba sincopado, outro referencial do "samba malandro") se paga: palavras e melodia de um samba que lhe entrega zombeteiro um comentário. Se Seu Bento inspira ternura, o narrador lhe dá algo que o leva ao silêncio. A situação pode ser banal, pode ser arquetípica dessas situações no universo do samba, pode ser cotidiana nos espaços onde o samba é a festa do dia, o encontro, a roda - mas o drama individual e conjugal, até pela religiosidade blasfemada ("ela fez até promessa/pagou e se arrependeu") é doloroso para quem o vive: acalanto para o pobre diabo, ironicamente "Bento" sem bênção, consolo que lhe atende as expectativas, mas que o cala pelo sono. Quanto ao "corpo" do último episódio é anônimo, não é de nenhum conhecido, mas é também familiar ao universo representado: fim de noite, velas, pandeiro. O mundo impõe o silêncio ao respeitoso boêmio egresso do samba. E o corpo morto aqui é investido de silêncio absoluto, diferente do silêncio a que, no limite, tendem os corpos vivos, pura presença, da relação sexual que o narrador-boêmio-cantor quer mais uma vez e obterá ("as mesmas palavras/o mesmo remorso... aquele sorriso"). Digo "silêncio absoluto" porque no "corpo morto" o silêncio não se reverterá em nova fala. Tender ao silêncio nessa canção significa, por fim, entregar-se ao silêncio reflexivo, a uma meditação, de forma a absorver o aprendizado do mundo, acreditando em sua lição aberta. O samba puro se posta na linha do horizonte a que se quer chegar. E não me parece ser aqui o caso de malandragem, pois nesse limite está o "não-falador", o receptivo (não o passivo!) ao mundo, aos mistérios tecidos 
na narrativa do cotidiano mais banal. Não há malandragem nessa ambiguidade, até porque a malandragem é absorção apenas daquilo que mantém seu estatuto, é a reprodução ad infinitum da opacidade de um discurso que manobra o verdadeiro e o falso de modo a ludibriar e não ser ludibriado, uma outra espécie de redoma, diferente e até oposta daquela onde se abriga o amor. Redoma que não se quer abrir ao mundo, pois julga-se infensa ao enganoso. Olha, portanto, de cima, como a ostentar uma superioridade de quem "vence" o mundo. Em outras palavras, o discurso malandro é mantenedor apenas do que confirma a identidade do malandro, não é abertura para a "verdade" do mundo. Segundo Carvalho, o discurso da malandragem, estudado no caso em Ismael Silva, baseia-se numa "jura" de fidelidade a si próprio: "Do seu reduto de fruição, a orgia, o malandro como ser em disponibilidade, resiste à perda da própria identidade" (CARVALHO, 1980, p. 73). Em "Coisas do mundo, minha nega" a disponibilidade do cantor olha de fora a própria malandragem e a esgarça, em direção a um aprendizado muito mais amplo. ${ }^{2}$

"Coisas do mundo, minha nega", ocupando posição estratégica na obra de Paulinho da Viola, uma vez que se pode considerar (como aqui o faço) como seu primeiro momento autoral significativo e que ele não se cansará de valorizar ao longo de toda a carreira - a canção foi gravada inicialmente em 1968, regravada em Memórias, disco de 1976, em Bebadachama, de 1997, e está no filme recente de Izabel Jaguaribe dedicado a Paulinho, Meu tempo é hoje - assim como estratégicas eram de certa forma as canções mais significativas de seus companheiros de geração de festivais naqueles anos, manifesta um desejo de aprendizado que se coloca mais no início do que no fim da narrativa que, no entanto, a moveu. Em "Venho do samba há tempo" reponta ainda outro sentido: o de "sair" do samba para de fato abrir-se às "coisas do mundo", ir até o limite do mundo, experimentar um olhar "de fora" do universo do samba. E essa abertura, esse desejo de aprender parece partir de uma recusa - ou pelo menos de um distanciamento - implícita a toda uma estereotipia que envolve a narrativa e, pelo universo representado nela, por extensão envolve

2. Em reforço a essas observações o próprio Paulinho da Viola, em depoimento ao autor, assim discorreu sobre o "discurso da malandragem": "o malandro não pode ter uma vida comum, como as outras pessoas. O malandro... (...) não ama; ele pode ser amado por muitas mulheres e tal... mas não ama (...) esses tipos na verdade são muito solitários porque eles não confiam em ninguém. É um discurso de um egoísmo, de defesa do "eu não ganho nada de ninguém e não dou nada pra ninguém." 
o mundo do samba. Um universo que se traduz em estereótipo, que é assim habitualmente traduzido, o do samba carioca, é aqui submetido a um enfoque de distanciamento que roça por essa estereotipia, mas que recusa aderir a ela: esta é uma das grandes linhas de força da poética do Paulinho da Viola a partir de então. Arthur Nestrovski, entrevistando Paulinho em 2002, percebe esse distanciamento justamente em relação ao samba que analisamos. Leia-se:

[Nestrovski] Se eu tivesse de dizer que alguma coisa me lembra, não sua música, mas uma visão de mundo, mesmo, eu diria que está no Cartola. Certo sentimento de distância, um olhar menos aderido, mais solitário. 'As coisas estão no mundo, só que eu preciso aprender'.

[Paulinho] É... Acho que sim. Mas o Cartola... tudo o que você disser, não é (...)Deixe eu lhe dizer uma coisa. A minha paixão por esse pessoal, minha admiração sempre foi tão grande, que eu sempre tive a sensação, como tenho até hoje, de que não fiz uma única coisa que se aproximasse do que eles fizeram. (...) Daquilo que eu fiz, tem o que eu gosto, e o que não. Mas aquela sensação de: olha, fiz um samba à altura de um samba do Zé [Kéti], à altura de um samba do Candeia... Isso nunca. Esse distanciamento que vocês percebem é um pouco assim. Eu sei que tive um trânsito dentro do samba. Convivi com muita gente, toquei em escolas etc. Mas é um mundo que é muito maior do que eu (NESTROVSKI, 2002, p. 6).

Tirando a primeira frase, aliás muito característica da fala parentética das declarações do compositor em entrevistas, que pode remeter tanto à visão de Paulinho sobre Cartola quanto à maneira como ele, Paulinho, percebe a inutilidade de o analista (qualquer analista) tentar abarcar o universo do mestre mangueirense, mas excetuando-se essa frase inicial, percebemos o quanto sua meta(auto)poética confirma o que vínhamos afirmando a respeito da questão do distanciamento entre esse cancionista dos anos 60 e o universo do qual se sentia tão perto, e tematizava com familiaridade incomum, o do samba. Esse enfoque, simultaneamente interno e externo, que se reconhece em ubiquidade e nos dá a ver com toda a nitidez os elementos que compõem tal universo, desde a "viola" abrasileirada de seu nome artístico até os personagens estereotipados que o texto fez desfilar ante nossos olhos, parece - e daí o desconcertante - emergir de uma ausência enunciativa, ou pelo menos ex-ótica a esse mesmo universo. Isso é tanto mais intrigante porque tal distanciamento demanda esforço para ser percebido, já que lança mão 
de recursos, diríamos "estilísticos", não dissociados, mas associados a esse universo. Só que estes, por sua vez, encontram-se em uma tensão construtiva da "nova" voz poética que não vem para reforçar, mas para problematizar essa estereotipia, ou melhor, em clave paradoxal: vem reforçar o universo do samba ao tomá-lo amorosamente como problema. À guisa de exemplo, se fizermos o jovem Paulinho e o jovem Chico Buarque dialogarem, estaremos em Paulinho muito distantes do malandro sestroso de "Juca" ou dos queixosos espirituosos abandonados de "A Rita" ou "Quem te viu, quem te vê", valiosas pepitas paradigmáticas da fase inicial do autor de "A banda", com sua profusão de estereótipos (o delegado, o meliante, o disco de Noel, o passista desdenhado pela cabrocha, etc.). A pista para entendermos o paradoxo parece estar em que aquilo com que um, Chico, lida como se fora um universo fechado, encerrado em si, concluído, de forma a ser glosado (genialmente) de fora, o outro, Paulinho, toma a partir de um de dentro. Em Paulinho, se há essa "glosa", ela se restringe a alguns poucos sambas iniciais, ainda que predominantes em sua poética de aprendizado, sua primeira fase, nos discos anteriores a seu primeiro LP individual, sambas como "Conversa de malandro", "Responsabilidade", ou no viés lírico-amoroso solene de "Arvoredo" e "Minhas madrugadas"(com o parceiro Candeia), que não chegam a se tornar paradigmáticos de sua assinatura autoral. No primeiro LP individual essa glosa de uma tradição estereotipada estaria apenas no samba-choro "Sem ela eu não vou"; em Chico, a "glosa" ocupa boa parte de seus três primeiros discos. Assim, podemos dizer que nesta canção analisada o aprendizado anterior e interior ao que se representa como o "universo do samba" precisa levar em consideração o que não aí não se encerra, o que lhe é externo, que também por sua vez deve ser aprendido. O samba de Paulinho da Viola quer fazer seu trânsito em relação a um universo midiático (por que não?) mais amplo. Naquele momento... o das canções de festival.

Nesse sentido, não é só em sua estrutura mais externa, seu longo texto de que falávamos no início, que esta canção se alinha na estética geracional daqueles anos - pressupondo-se, claro, que se possa falar nesses termos, e creio que sim. Ela engaja-se precisamente num projeto que, sem dar as mãos ao projeto tropicalista, tampouco se filiaria à linha de força de resistência a esse mesmo projeto, no qual a "autenticidade nacional do samba" ou da folk song "nordestinizante" do protesto deveria ocupar o papel de vigilante armada. Paulinho 
sempre se postou equidistante das simplificações, das "respostas urgentes" que envolveram tais discussões encarnadas no "tempo presente," não como mero espectador, mas ostentando posição ativa e altiva, embora tenha pautado seu percurso pelo caráter inenfático que sua obra assumirá definitivamente. E sem abrir mão do enorme manancial do samba, o investigará sem furtar-se a fruílo de dentro, numa obra em que procedimentos consagrados da linguagem da tradição decantam-se em direção a uma voz autoral, a uma obra personalíssima: "bebadosamba/bebadachama" é o dístico das coisas do mundo uma vez aprendidas, como está no seu trabalho de 1997. Já parece suficiente que a simples retomada da mesma canção ao longo de quatro décadas, registrando-a nos discos, pode apontá-la como ponto de grande importância em sua poética.

\section{Referências bibliográficas}

BOSI, Alfredo. O ser e o tempo da poesia. São Paulo: EDUSP; Cultrix, 1977.

CANCLINI, Néstor García. Culturas híbridas: estratégias para entrar e sair da modernidade. 4a . ed. São Paulo: EDUSP, 2004.

CARVALHO, Luiz Fernando Medeiros de. Ismael Silva: samba e resistência. Rio de Janeiro: José Olympio, 1980.

CÍCERO, Antônio. O tropicalismo e a MPB. In: DUARTE, Paulo Sérgio et NAVES, Santuza Cambraia (Org.). Do samba-canção à tropicália. Rio de Janeiro: Relume Dumará; FAPERJ, 2003, p. 201-214.

MATOS, Cláudia (Neiva de). Acertei no milhar: samba e malandragem no tempo de Getúlio. Rio de Janeiro: Paz e Terra, 1982.

NAPOLITANO, Marcos. "Seguindo a canção": engajamento político e indústria cultural na MPB (1959-1969). São Paulo: Anablume; FAPESP, 2001.

NESTROVSKI, Arthur et RAMOS, Nuno. O sambista sem saudades. Folha de S. Paulo, São Paulo, 25 agosto 2002, Mais!, p. 6-10.

TATIT, Luiz. O cancionista: composição de canções no Brasil. São Paulo: EDUSP, 1996.

Recebido em 02 de maio e aprovado em 14 de junho de 2011.

3. A questão do "tempo presente" se constitui quase que num topos da poesia moderna entre nós, adquirindo foros de verdade absoluta ao dizer de um - que por vezes se quer obrigatório - "sentimento do mundo". Sua formulação mais célebre está no Drummond de "Mãos dadas": "Não serei o poeta de um mundo caduco / (...) O tempo é a minha matéria, o tempo presente, os homens presentes, a vida presente". 